\title{
AC 2011-1353: CREATING GREEN THINKING ENGINEERS THROUGH THE CREATION AND USE OF AN INDUSTRIAL ENERGY MANAGE- MENT COURSE
}

\section{Donald C. Richter, Eastern Washington University}

DONALD C. RICHTER obtained his B. Sc. in Aeronautical and Astronautical Engineering from The Ohio State University, M.S. and Ph.D. in Engineering from the University of Arkansas. He holds a Professional Engineer certification and worked as an Engineer and Engineering Manger in industry for 20 years before teaching. His interests include project management, robotics /automation, Energy Management and air pollution dispersion modeling 


\title{
Creating Green Thinking Engineers Through the Creation and Use of an Industrial Energy Management Course
}

\begin{abstract}
Teaching engineering and engineering technology students to think "green" and to recognize energy saving opportunities in industrial facilities is an important way to reduce our nation's energy footprint. Engineers need to be able to identify and quantify the energy savings opportunity in the industrial setting. This paper discusses the creation and implementation of an Industrial Energy Management course to introduce the skills needed to perform energy audits in industrial facilities. The paper will discuss the philosophy and curriculum developed to allow the student to recognize how to spot energy saving potential projects, then how to calculate the savings for the proposed project. The author will discuss how he drew upon his past experience in an Industrial Assessment Center ( IAC $)^{7}$ leading over 90 Industrial Audits using undergraduate students to develop the curriculum for the Industrial Energy Management course. Through the use of this past experience a model for an industrial energy audit procedure is presented and incorporated in the course. Students are exposed to several case studies to illustrate and practice the ability to calculate the energy savings, implementation cost and using industrial utility bills calculate the savings along with a simple payback. Students are taught how to propose the energy savings projects to make management understand the advantage to implementing the proposed projects. The paper will also discuss the lessons learned from teaching the course and plans for the future course development. The model for the course presented should be easily transported to other institutions and should help other faculty to develop courses that can help create a new "green" thinking student who can then go out into industry and make a difference in our nation's energy usage.
\end{abstract}

\section{Introduction}

Universities have a responsibility to train the future engineers of our country to think green in managing the resources that we use in industrial facilities. Training students to recognize energy saving opportunities in industrial facilities will help reduce our nation's energy footprint. Using these new green thinking skills will also help industry to compete in the new world economy. Production costs ( in constant dollars) can be decreased or at least increases will be less as we become more efficient in how we produce products by reducing the energy we use. Utilizing effective energy management is one of the most promising cost reductions and thus profit improvement program available to industry today ${ }^{1}$. Many of these energy saving projects have lead to high returns on the investment to install and thus can produce rapid paybacks ${ }^{2}$. The industrial and commercial sectors make up over $45 \%$ of the total energy demand in the United States $^{4}$. If we can reduce this demand we can greatly impact the nations demand on energy. We are severely dependent on fossil fuels to meet this demand. Currently $83 \%$ of the energy supply is met by fossil fuels in the United States ${ }^{3}$. Fossil fuels will only increase in price. The U.S. Energy Information Administration projects the cost of oil alone to increase to as high a \$133/ 
barrel in 2035 ( using constant 2008 dollars) ${ }^{5}$. Costs for energy will continue to increase as the global demand for energy is projected to increase $49 \%$ from 2007 to 2035 even with the U.S. making up a less percentage of the total global demand, 20\% in 2007 down to $16 \%$ of total global energy demand by $2035^{3}$. We are already behind the some of the industrial nations in addressing energy savings within each company. One example is Japan which has a law that requires that every industrial plant must have a full-time energy manager ${ }^{1,6}$. Clearly we have a lot of ground to make up.

The above data leads us to the conclusion that we need to train engineers to identify cost saving potentials in industry to try to minimize the effect of the nations great demand on energy in both an attempt to become better stewards of the earth's resources and to better compete in the global economy. Currently engineering and engineering technology curriculums teach the underlining science and theory needed to accomplish this goal in industry but do not connect the topics in an intergraded approach to help engineers become both aware and competent in proposing energy saving projects to their companies. Many, if not most, engineers have never seen or understand how the energy their facility is used or how it is billed. They are therefore not adept in how to calculate the savings using these bills. The billing structures vary and are somewhat complicated to analyze. Therefore, there is a need to develop a course that takes the mystery out of the process of identifying and presenting energy saving projects. This includes presenting a method to understand the energy uses in a facility, how to analyze the energy bills and then to identify and quantify savings including simple pay back calculations. The course would need also to describe how an energy audit should be conducted and how energy/cost savings should be presented to management. We must never forget we need to be able to present a clear and understandable argument for each project or even the best of ideas will never be funded or implemented.

\section{Course Description and Framework}

The course has been patterned on the training the author used to give to undergraduate students who worked in one of the nation's Industrial Assessment Centers (IAC). The IAC's are grant funded centers funded through the U.S. Department of Energy-Energy Efficiency and Renewable Energy. Detailed information on the IAC centers is available on the web site given in reference 7. Teams of students were trained and lead by a faculty member to perform industrial energy and productivity audits at industrial facilities. The author led over 90 of these audits.

The basic structure of the course on a quarter system is five credits, four hours of lecture per week and two hours of laboratory per week. During the course of the quarter the student learns the development of the energy audit procedure including energy saving calculations for industrial settings. The student develops and explores the creation of industrial energy audits through the extensive use of case studies. The student is presented the structure and outline of an energy audit process including learning how to identify and classify the parts of the energy audit. 
Then the student is introduced to the method of billings used for electric, natural gas, oil, water and sewage. Time is spent reviewing typical sample billing structures, how the bills are calculated including how plant operations can have a major effect on the monthly bill. Concepts of demand vs. usage and time of day usage are covered. The student is then taught how to compute an average saving value on demand and usage of the different types of energy resources. The student is instructed on how to plot and present the data to be meaningful for future calculations on energy savings. Economic analysis and life cycle costing are introduced and practiced by the student. These form the basis for the case studies used in the rest of the course. The Student is able through the course to identify and quantify the major energy consuming equipment in an industrial facility. Case studies are then used to illustrate the savings that can be derived from a study of the various systems found in most industrial facilities. Following is a brief description of some of the systems and types of energy saving case studies used in the course. Case studies were used to simulate an actual industrial energy audit in an attempt to give the student a similar experience of participating in an industrial audit without having to actually travel to an appropriate facility. The use of case studies also allowed the student to work on many types of energy saving projects that most likely would not all be present in one audit but would take several audits to get the same experience. Following are some of the more common energy saving projects the student works on through the use of case studies during the term of the course.

The typical industrial lighting systems are described in detail since 30-70\% of the energy in commercial building and 5-25\% of the energy in industrial plants is in the lighting system. ${ }^{1}$ The advantage and disadvantage of each type of lighting system is discussed and as well as the minimum lighting level standards for various tasks. Energy saving calculations for changing ballast/lamp combinations as well as using different lighting schemes are performed.

The heating, ventilating and air conditioning system types and configurations found in industrial plants are briefly discussed with advantages and disadvantages explained to the student. Case studies for using heat/cooling recovery techniques are presented and through the use of case studies the student calculates energy saving project in this area. The option of using a plate and frame heat exchanger for "free cooling" is presented and energy savings calculations are performed.

The various types of boilers are discussed and the cost saving advantages to keeping a boiler air /fuel ratio tuned are illustrated through a case study. Energy saving strategies for heat recovery from the boiler stack is discussed and cost saving examples demonstrated. The typical steam distribution system is reviewed including the identification of energy cost saving potential projects. These cost saving projects include insulation, condensate returns, low pressure condensate return tanks and steam leaks/steam trap maintenance.

Discussions of electrical equipment and motor efficiency are explored along with variable frequency drive systems for fans and pumps. Energy and cost saving calculations are preformed 
use a case study. The concept of "power factor" is also discussed including how these affect the power bill along with basic options for power factor correction.

The typical design of a plant air systems including energy saving projects is presented. Cases studies are used including air leakage are illustrated through case studies and examples. Small energy projects such as v-belt changes are calculated by the student to illustrate that small individual savings applied throughout the plant can have a sizable effect on overall energy savings.

Basic Passive solar and green building design concepts are introduced as well as how to think green on product design and process improvements each of which can affect the energy foot print of the company.

Resources that the student can use in his future career are presented including the "Modern Industrial Assessments A Train Manual"7, EPA Guide to Industrial Assessments for Pollution Prevention and Energy Efficiency ${ }^{8}$, and Self Assessment Workbook for Small Manufacurers ${ }^{9}$.

The following is a summary listing of the learning objectives with their mapping to ABET criteria.

Learning Objectives and Corresponding Mapping to ABET Criteria 2: Upon completion of this course, students will be able to:

1. Identify and classify the parts of and energy audit process. (Criteria $a, b$ and $f$ )

2. Describe how technologies are inter-related. (Criteria $a, b$ and $f$ )

3. Understand and calculate the various types of energy usage in a plant (Criteria $a, b, g$ and $k$ )

4. Perform Economic analysis of utility bills and life cycle costing. (Criteria $a, d, g$ and $k$ )

5. Evaluation of energy usage of lighting system. (Criteria $a, b$ and $f$ )

6. Evaluation of energy usage and energy saving strategies of Heating Ventilating and Air Conditioning. (Criteria $a, b$ and $f$ )

7. Calculate energy saving techniques for Steam systems including Boilers. (Criteria $a, b$ and $f$ )

8. Indentify and quantify the major energy consuming equipment in a industrial facility.(Criteria $a, b$ and $f$ )

9. Understand the effects of power factor on energy usage and strategies for power factor correction. (Criteria f)

10. Indentify and calculate energy savings in compressed air systems. (Criteria a, $d$ and $f$ )

11. Indentify strategies for energy savings for process heat transfer systems. (Criteria $a, d$ and $f$ )

12. Conduct an energy audit for an industrial facility. (Criteria a, g, h, and k)

\section{Lessons Learned}

Covering all of the above in the frame work of a 10 week quarter is a daunting task for both the instructor and the student. The course was taught the first time as a 4 credit lecture only class. This did not give the student adequate time to work on the case studies and correct any problems with the first attempt of a case study. Students commented that the pace was so fast that they were not able to explore as a group the various options for a given case study. Case studies 
assigned turned out to be more of a homework problem with little chance for feedback during the assigned case study. In response to these concerns a two hour laboratory was added to each week to allow the students structured time to meet in a team environment. The hope is that the laboratory time will allow more time to explore the various options for an energy saving project. This also allows structured time with the instructor to interact and lead discussions on why one option might be advantageous over another without the press of trying to move on to quickly to cover the lecture topics scheduled for the day.

\section{Conclusions, Reflections and the Future}

The Students responses and interest in the course have been very positive. They are appreciative of a course that "puts it all together" for energy savings calculations. Often students see courses as separate "silos" and do not appreciate that the basic technical skills that they receive in a four year education will need to be used in concert with each other to accomplish an overall goal or project. The course allows the connections between these so called course silos and provides practice in a team environment. The students were correct in their concern that they would benefit from a formal laboratory/seminar to have a mentor available to lead discussions on the energy saving proposals.

The course can be easily duplicated at any institution regardless if they are in a large industrial area or not by the use of case studies. The use of case studies also allows students to study the opportunities that a single actual audit may not afford depending on the plant visited. Training our future engineers to look for energy saving opportunities will help us all reduce the carbon foot print of our nation. Through the insights gained by the course these future engineers will also think more green energy efficient in the original designs they perform since they will now have the tools to evaluate options and present the long term savings of a greener energy design that might have a slightly more initial cost. It is hoped that more programs will find room in their programs for a similar course to the one presented in this paper.

\section{Bibliography}

1. Capehart, B. L., Turner, W. C. \& Kennedy, W.J., (2008). Guide to Energy Management Sixth Edition, Fairmont Press, ISBN 978-1-4200-8489-4.

2. Doty,S. \& Turner, W. C. (2009). Energy Management Handbook Seventh Edition, Fairmont Press, ISBN 978-14200-8870-0.

3. U.S. Energy Information Administration, International Energy Outlook 2010, DOE/EIA-0484(2010) Retrieved December 22, 2010, from www.eia.gov/oiaf/ieo/index.html.

4. U.S. Energy Information Administration, Annual Energy Review 2009, DOE/EIA-0383(2009) ) Retrieved December 22, 2010, from ww.eia.gov/oiaf/aeo/index.html.

5. U.S. Energy Information Administration, Annual Energy Review 2011, DOE/EIA-0383(2009) ) Retrieved December 22, 2010, from ww.eia.gov/oiaf/aeo/index.html. 
6. The National Energy Strategy, Chater on Industrial Energy Use, U.S. Department of Energy, Washington, D.C., April 1990.

7. Modern Industrial Assessments A Training Manual Version 2.0, Muller, M, Simek, M., Mak, J., Mitovic, B.., The Office of Industrial Productivity and Energy Assessment 2001, Rutgers University, www.iac.rutger.edu/redirect.php?rf=industr_title_toc

8. Guide to Industrial Assessments for Pollution Prevention and Energy Efficiency, U.S. Environmental Protection Agency Office of Research and Development National Risk Management Research Laboratory Center for Environmental Research Information, Cincinnati, Ohio ,EPA/625/R-99/003 June 2001.

9. Self Assessment Workbook for Small Manufactures Version 2.0, Muller M., Papadarntsakis, K, Center for Advanced Energy Systems Rutgers University, www.iac.rutgers.edu/redirect.php?rf=selfassessment.. Social Design Notes (2003). What is Universal Design? Retrieved from http://www.backspace.com/notes/2003/08/what-is-universal-design.php 